\title{
Equality and Access to Credit: A Social Contract Framework
}

John Linarelli

Touro Law Center, jlinarelli@tourolaw.edu

Follow this and additional works at: https://digitalcommons.tourolaw.edu/scholarlyworks

Part of the Banking and Finance Law Commons, Consumer Protection Law Commons, Jurisprudence Commons, and the Law and Economics Commons

\section{Recommended Citation}

John Linarelli, Equality and Access to Credit: A Social Contract Framework (September 13, 2020). Law and Contemporary Problems, Vol. 84, No. 1, 2021

This Article is brought to you for free and open access by the Faculty Scholarship at Digital Commons @ Touro Law Center. It has been accepted for inclusion in Scholarly Works by an authorized administrator of Digital Commons @ Touro Law Center. For more information, please contact Iross@tourolaw.edu. 


\title{
EQUALITY AND ACCESS TO CREDIT: A SOCIAL CONTRACT FRAMEWORK
}

\author{
JOHN LINARELLI* \\ I \\ INTRODUCTION
}

Most Americans assume that debt is mainly about transaction and choice in a market. ${ }^{1}$ But in the United States and some other advanced economies, debt is much more than some isolated transactions independent of government policy. Debt is often what social scientists and philosophers describe as a social good, the distribution of which determines the life chances of individuals, children, and entire families. The social good aspect of debt has not been lost on governments and politicians. In many advanced economies and particularly in the United States, debt-or its converse, access to credit-is predominantly social and political, with extensive government involvement in deciding who gets credit and who does not. A substantial amount of private debt in the United States is subsidized or guaranteed by the federal government. ${ }^{2}$ The Federal National Mortgage Association (Fannie Mae) and Federal Home Loan Mortgage Corporation (Freddie Mac), two government sponsored enterprises (GSEs), guarantee about $\$ 7$ trillion in U.S. home mortgage debt, over ninety percent of all mortgage debt in the country. ${ }^{3}$ Even after the last financial crisis in 2008-2009, the U.S. federal government remains substantially involved in making the mortgage securitization market possible, which fuels the very existence of the thirty-year fixed rate mortgage. Extensive federal regulation of the market, including an array of disclosure laws, regulation of terms and transaction structures, and laws banning discrimination in lending, has existed for quite some time. $^{4}$

Institutions in American society enforce what sociologist Rachel Dwyer characterizes as a credit-welfare state tradeoff: subsidized debt promotes well-

Copyright (C) 2021 by John Linarelli.

This Article is also available online at http://lcp.law.duke.edu/.

* Professor of Law, Touro College Jacob D. Fuchsberg Law Center. My deepest appreciation to participants at the Financial Inclusion, Access to Credit, and Sustainable Finance symposium hosted by Durham University Law School on May 28, 2019 for valuable comments. All errors are mine.

1. See Suzanne Mettler, The Submerged State: How Invisible Government Policies UNDERMINE AMERICAN DEMOCRACY 4 (2011) (claiming that because the majority of government aid is an in-direct subsidy, many taxpayers are unaware of the significant impact the aid has on the market).

2. SARAH L. QUinN, AMERICAN BondS: How CREDIT MARKETS SHAPED A NATION (2019).

3. Bruce Mizrach \& Christopher J. Neely, Fed Intervention in the To-Be-Announced Market for Mortgage-Backed Securities, ECON. SYNOPSES, Apr., 2020, at 1.

4. See discussion infra Part II. 
being and social mobility in lieu of a strong set of public benefits programs. ${ }^{5}$ This is a precarious tradeoff, which makes people and families vulnerable. The tradeoff converts duties of justice owed collectively to persons into contractual obligations owed individually by persons. Debtor-creditor relationships tend to be unequal by their very nature and structure. ${ }^{6}$ Usually the debt underlying this imbalanced relationship is secured debt that can be over four times annual household income, such as the home mortgage. ${ }^{7}$ But if a family is excluded from the benefits of secured debt the result is the opposite: a credit-based society in which credit is a resource that contributes to inequalities. ${ }^{8}$ About 45 million Americans lack a credit score as of 2015, essentially excluding them from accessing credit. ${ }^{9}$

The winners and losers that the law determines in a debt-for-well-being society can reproduce invidious forms of racial or other discrimination, causing grave injustice and substantial harm for many persons, families, and communities - harm that spans across generations. In the pre-civil rights era of the twentieth century, governments used law to block African-Americans from obtaining home mortgages by deeming them too risky and through a practice known as redlining-the exclusion of entire minority communities from mortgage credit. ${ }^{10}$ Governments have historically structured markets to achieve injustice with intergenerational consequences.

Beyond the normative issues of fairness or justice in the credit system, some regulatory design is ineffective at producing even the most basic levels of consumer protection. As Part II of this Article explores, the primary mode of regulation in financial markets is disclosure. The problems with disclosure have mainly to do with cognition: the limited ability of persons to be able to use and process information to make informed lending decisions. Substantial evidence in repeat studies informs that mandatory disclosure fails to protect consumers. ${ }^{11}$ Attempts to infuse more paternalistic structures into the debt contract risks increasing the costs of credit for lenders which may cause them to exit the credit

5. Rachel E. Dwyer, Credit, Debt, and Inequality, 44 ANN. REV. SocIO. 237, 245 (2018).

6. Id. at 238

7. What is a debt-to-income ratio? Why is the $43 \%$ debt-to-income ratio important?, CONSUMER FIN. PROT. BUREAU, https://www.consumerfinance.gov/ask-cfpb/what-is-a-debt-to-income-ratio-why-isthe-43-debt-to-income-ratio-important-en-1791/ [https://perma.cc/4EG2-TNVF].

8. See Dwyer, supra note 5, at 243 ("[S]ecured debt in a context of a weak welfare state enables households with modest means to build wealth over time, and exclusion from such opportunities contributes to inequalities in attainment and wealth accumulation.").

9. CONSUmer Fin. Prot. Bureau, DAta Point: Credit InVisibles 15 (2015), https://files. consumerfinance.gov/f/201505_cfpb_data-point-credit-invisibles.pdf [https://perma.cc/2A9F-FQRL].

10. See Richard Rothstein, The Color of LAw: A Forgotten History of How OuR GOVERNMENT SEGREGATED AMERICA 16-17 (2017) (explaining the practice of red-lining and the discriminatory impact it had on black communities).

11. See discussion infra Part II.A. 
market in areas where credit is needed most. Finance has a way of easily moving credit around to seek the higher returns and lower risk. ${ }^{12}$

Call it the tragedy of contract. The core of debt is contract. A mix of normative and cognitive problems can lead to the dismal conclusion: it is very difficult to regulate access to credit in a way that both fairly distributes credit as a resource in a society, while also ensuring that debtors are respected as autonomous agents who avoid unsustainable levels of debt. Both these problems concern fairness. Regulating the terms of the debt contract has to do with transactional fairness, which is an attempt to make consumers assent to a contract that is psychologically sensible to persons. The distribution question concerns substantive fairness: access to credit is what John Rawls called a social primary good and leads to access to other social primary goods, requiring a fair distribution in a society along egalitarian lines. ${ }^{13}$

Part II of this Article explores the cognitive limitations that people encounter in making credit decisions. Regulatory disclosure mandates are generally ineffective at improving the choices people make about debt. People do not read contracts and what they do read they often fail to understand. The contract model, which puts overwhelming cognitive demands on people, is preordained to fail. Creditors will not disclose what they do not have to, and they sometimes engage in psychological manipulation to entice people to take on debt. Part II also examines why more paternalistic attempts to regulate the actual terms and conditions of debt products are often ineffective.

Part III explores the normative questions of why access to credit is an important social good in a society that creates access to other important social goods such as housing, education, and intergenerational well-being. The current framework, which denies that access to credit is an important social good, puts persons and households in a precarious and vulnerable position, fails to meet goals of well-understood theories of distributive justice, and leads to a denial of liberty for individuals in the form of domination by creditors. The conclusion is clear: either develop a set of tools to incorporate the values of equality into the consumer lending markets, or remove debt from the basic structure of society and eliminate its role as a social good that allocates well-being. Societies must be careful not to over-financialize their citizens. ${ }^{14}$ Financialization requires the recognition of justice as a priority for law and policy on access to credit.

12. See Katharina Pistor, The Code of Capital: How the Law Creates Wealth and INEQUALITY 199 (2019) " "Spotting opportunities to make money on the hope of others is what intermediaries do, and their business is leveraging up in the expectation of future returns.").

13. See discussion infra notes $46-49$ and accompanying text.

14. See generally GUIDO COMPARATO, THE FINANCIALISATION OF THE CitizEN SOCIAL AND FinANCIAL INCLUSION THROUGH EUROPEAN PRIVATE LAW (2018) (discussing the concept of financialization). 


\section{COGNITIVE Difficulties In REGUlating THE DEBT CONTRACT}

This Part discusses the cognitive obstacles preventing humans from making good credit decisions. Though these cognitive obstacles are now well understood, legal scholars have offered little by way of policy prescriptions to work around them. The immediate reaction among many who want to protect weaker parties to debt contracts is to impose restrictions on lenders, but such moves risk restricting access to credit. ${ }^{15}$ This is not a solution in a world where access to credit is embedded in the basic structure of a society as necessary for household and intergenerational flourishing. ${ }^{16}$ Legal scholars and regulators appear to embrace a resigned attitude toward the situation and do not pursue bold solutions. Oren Bar Gill argues that the focus on disclosure mandates is not because it is always the "optimal form of regulatory intervention" but because it is the "least intrusive form of regulation and, thus, the form of regulation most likely to be adopted."17 We seem stuck in the tragedy of contract. This resignation appears to be at work in the private law for consumer contracts, in which conspicuous notice of contract terms is beginning to replace mutual assent as sufficient to form a contract online. ${ }^{18}$

This failure to pursue bold strategies is a predictable outcome in the social science (as opposed to normative) approaches dominating legal scholarship. The analytical and empirical methods being used are suitable for identifying problems but not for furnishing a normative framework by which to evaluate and design regulation. We cannot ask social science to do much more than identify problems. The study of justice has become less important, often labeled as a question that

15. See John Linarelli, Debt in Just Societies: A General Framework for Regulating Credit, 14 REGUL. GOVERNANCE 409, 409 (2020) ("[A]ccess to credit is a 'resource' in many societies, which means that it is a primary method by which persons develop and implement plans for their lives.").

16. Id.

17. OREn BAR-Gill, SEDUCTION By CONTRACT: LAW, ECONOMICS, AND PSyCHOlOGy IN CONSUMER MARKETS 32 (2012).

18. See Meyer v. Uber Tech. Inc., 868 F.3d 66, 74-75 (2d Cir. 2017) (noting that an offeree is bound by an agreement regardless of actual notice to a term if the term if the term was clear and conspicuous enough that a reasonably prudent user would be on inquiry notice). On these issues is it worth reviewing the considerable debates around the Restatement of the Law of Consumer Contracts, which the American Law Institute completed in 2019. See generally Oren Bar-Gill, Omri Ben-Shahar \& Florencia Marotta-Wurgler, Searching for the Common Law: The Quantitative Approach of the Restatement of Consumer Contracts, 84 U. CHI. L. REV. 7 (2017) (outlining the empirical approach taken to construct the Restatement of Consumer Contracts); Gregory Klass, Empiricism and Privacy Policies in the Restatement of Consumer Contract Law, 36 YALE J. ON REG. 45 (2019) (arguing that the new restatements coding has obscured the judgment calls necessary to properly code decisions and their persuasive power); Adam J. Levitin, Nancy S. Kim, Christina L. Kunz, Peter Linzer, Patricia A. McCoy, Juliet M. Moringiello, Elizabeth A. Renuart, \& Lauren E. Willis, The Faulty Foundation of the Draft Restatement of Consumer Contracts, 36 YALE J. ON REG. 447 (2019) (arguing that the coding of the restatement relied on irrelevant cases and thus does not adequately restate the law of contracts); Brian Wolfman, Opposition to the draft Restatement of the Law of Consumer Contracts, PUB. CITIZEN: CONSUMER L. \& POL'Y BLOG (May 2, 2019), https://pubcit.typepad.com/clpblog/2019/05/opposition-tothe-draft-restatement-of-the-law-of-consumer-contracts.html [https://perma.cc/H6B4-3RWP] (endorsing Adam Levitin's critique on the draft of the Restatement of the Law of Consumer Contracts). 
is rhetorical or about personal opinion. ${ }^{19}$ As we shall discover in Part III below, fully developed theories about justice and equality could be put to use in evaluating financial regulation. ${ }^{20}$ For now, let us survey the current state of affairs on regulatory design for access to credit.

\section{A. The Failure of Mandated Disclosure}

Disclosure has been the approach of choice in attempting to solve the problems of fairness in consumer financial services. The seventy-third United States Congress "invented" disclosure and made the United States the first country to mandate disclosure in financial transactions. Various provisions in the Securities Act of 1933 regulated the issuance of new investment products known as securities, and provisions in the Securities and Exchange Act of 1934 regulated the sale of securities after initial issuance, in the secondary markets. ${ }^{21}$ Conversely, the United Kingdom did not take government regulation of financial services seriously until 1985, with the creation of the now long-defunct Securities and Investment Board. ${ }^{22}$ The 1933 and 1934 "Securities Acts" in the United States influenced the style and method for securities and financial regulation to follow in the United States and in other countries. ${ }^{23}$

The 1933 and 1934 Securities Acts were not limited to consumer transactions, a concept that did not exist at the time. The core regulatory concept for American financial markets rests on disclosure, both in their regulation of securities issuers and in setting legal standards for suits to recover for various forms of fraud in the sale and purchase of securities. Substantial reasons support disclosure mandates

19. See Joseph William Singer, Normative Methods for Lawyers, 56 UCLA L. REV. 899, 933-34 (2009). These arguments go back to Bentham.

20. See discussion infra Part II.

21. Securities Act of 1933, Pub. L. No. 73-22, 48 Stat. 74, 74 (codified as amended at 15 U.S.C. § 77); Securities Exchange Act of 1934, Pub. L. No. 73-209, 48 Stat. 881, 889 (codified as amended at 15 U.S.C. $\S 78)$.

22. See Sam Scott Miller, Regulating Financial Services in the United Kingdom-An American Perspective, 44 BUS. LAW. 323, 330, 336 (1989) ("The failure of several investment advisory and commodity firms following their misappropriation of customers' funds earlier in the 1980's created a call for new legislation.").

23. The European Union has also mandated a significant disclosure regime with which EU member states must comply. There have been a number of critiques on the EU's over-reliance on disclosure. For critiques, see generally Ognyn Seizov et al., The Transparent Trap: A Multidisciplinary Perspective on the Design of Transparent Online Disclosures in the EU, 42 J. CONSUMER POL'Y 149 (2018) (arguing that a lack of guidance on how disclosures must be formulated leaves too much discretion to traders); Emilios Avgouleas, What Future for Disclosure as a Regulatory Technique? Lessons from Behavioural Decision Theory and the Global Financial Crisis, in THE FUTURE OF FINANCIAL REGULATION 211 (Iain MacNeil \& Justin O'Brien eds., Hart 2010) (arguing that disclosure will only be effective if in conjunction with supplemented with protected regulations); Emilios Avgouleas, The Global Financial Crisis and the Disclosure Paradigm in European Financial Regulation: The Case for Reform, 6 EUROPEAN CO. \& FIN. L. REV. 440 (2009) (arguing that an independent financial products committee could be a better protection strategy then enhanced disclosure). In a related vein about sales law. See Omri Ben-Shahar \& Oren Bar-Gill, Regulatory Techniques in Consumer Protection: A Critique of European Consumer Contract Law, 50 COMMON MKT. L. REV. 109 (2013) (arguing that the Common European Sales Law will likely impede cross border trade, prevent consumers access cross markets and create disharmony in the member states' laws). 
for public securities markets, which go beyond the paternalism rationales associated with protection of purchasers of securities. These reasons have mainly to do with making markets more efficient by promoting the disclosure of information that institutional investors will incorporate into their valuations of securities. This argument finds its rationale in the efficient capital markets theories and in Friedrich Hayek's The Use of Knowledge in Society. ${ }^{24}$

While mandated disclosure for securities rests only partly on a consumer protection rationale, particularly the protection of individual investors, the rationale for mandated disclosure in consumer financial products is designed primarily to protect the consumer. The "protect the market" rationale has some force in the regulation of credit products, but less than it has in securities markets, as it cannot as reliably rest on the notion of rational transactors in credit markets as it can for securities markets, in which institutional investors are the main consumers of information.

In consumer lending, a formidable patchwork of federal and state laws, starting with the Truth in Lending Act in 1968, mandate disclosure by lenders in some form to borrowers. ${ }^{25}$ This is particularly the case for mortgage lending, which connects to a primary source of wealth for many households in the United States and in other countries that promote individual homeownership. Current post-global financial crisis legislation in the United States mandating disclosure includes the Dodd-Frank Wall Street Reform and Consumer Protection Act $^{26}$ for home mortgages and the Credit Card Accountability, Responsibility, and Disclosure (CARD) Act $^{27}$ for credit cards, though these acts go further and engage in some product regulation. ${ }^{28}$

Recent empirical research on online consumer contracts offers evidence that disclosure mandates fail because people do not read terms and conditions. ${ }^{29}$ The

24. See generally Friedrich A. Hayek, The Use of Knowledge in Society, 35 AM. ECON. REV. 529 (1945).

25. Space prohibits listing them all here. See generally Anne Fleming, The Long History of "Truth in Lending", 30 J. POL'Y HIST. 236 (2018) (outlining the history and development of mandatory disclosure rules); Kathleen C. Engel \& Patrick A. McCoy, A Tale of Three Markets: The Law and Economics of Predatory Lending, 80 TEX. L. REV. 1255 (2002) (articulating the market structures that have incentivized private lending).

26. See generally Dodd-Frank Wall Street Reform and Consumer Protection Act, Pub. L. 111-203 124 Stat. 1376 (2010).

27. See generally Credit Card Accountability, Responsibility, and Disclosure (Credit CARD) Act of 2009, Pub. L. 111-24, 123 Stat. 1734.

28. See infra notes 34-36 and accompanying text.

29. See OMri Ben-Shahar, More Than You WAnted to KnOw: The Failure of MANDATED Disclosure 7 (2016) ("Mandated disclosure fails because it depends on a long chain of fragile links. It works only if three actors - lawmakers, disclosures, and discloses - play demanding parts deftly."); Florencia Marotta-Wurgler, Even More Than You Wanted to Know About the Failures of Disclosure, 11 JERUSALEM REV. LEGAL STUD. 63, 63 (2015) ("Nobody reads fine print - even when it matters."); Yannis Bakos, Florencia Marotta-Wurgler, \& David R. Trossen, Does Anyone Read the Fine Print? Consumer Attention to Standard Form Contracts, 43 J. LEGAL STUD. 1, 6 (2014) (finding in their study that less than $1 \%$ of users actually read the licensing agreement when online shopping). See generally Florencia Marotta-Wurgler, Does Contract Disclosure Matter?, 168 J. INST. \& THEORETICAL ECON. 94 (2012) (arguing mandatory disclosure will not likely put competitive pressure on sellers); 
evidence these studies have developed can be reasonably extended to contracting for credit, much of which now happens online. ${ }^{30}$ Many people have difficulties with financial literacy. ${ }^{31}$ And the argument that people who enter into online contracts are rationally ignorant rests on a by now well-understood false assumption that people are rational. There is now overwhelming evidence, in behavioral economics and in psychology and the behavioral sciences more generally, putting in deep suspicion the notion that we should rest policy law reform on a spurious conception of the person as rational..$^{32}$ The main dissenter from the view that mandated disclosure fails is Oren Bar-Gill, who contends that product use disclosure, particularly disclosure of individual as opposed to statistically determined average uses of credit products, may be effective. ${ }^{33}$ BarGill's work appears to apply to credit cards and other forms of revolving credits in which use patterns develop.

Except perhaps for this limited case, mandated disclouse fails.

But let us be clear on what mandated disclosure in consumer finance is meant to fix. It is meant to assist contract parties in positions of disparate bargaining power or at disparate levels of sophistication. Mandated disclosure is intended to support a person's autonomy as a contract party. It has really nothing to do with distributive justice. Laws that protect the vulnerable or persons with little bargaining power are aimed at fairness in individual transactions. Distributive justice has a broader role, focusing not on the individual responsibility of the parties to each transaction but on the social responsibility members of a society have to structure their credit markets fairly. At best, if mandated disclosure works - a big "if" - it might accidently achieve some distributive justice. But we need methods more precisely designed to focus on distributive justice.

Florencia Marotta-Wurgler, Some Realities of Online Contracting, 19 S. CT. ECON. REV. 11 (2011) (discussing the policy implications of End User License Agreements); Omri Ben-Shahar \& Carl E. Schneider, The Failure of Mandated Disclosure, 159 U. PA. L. REV. 647 (2011) (arguing mandatory disclosure leads to unintended consequences and harms those it aims to protect).

30. See Lauren Willis, Decisionmaking and the Limits of Disclosure: The Problem of Predatory Lending: Pricing, 65 MD. L. REV. 707, 727 (2006) ("The prices for their other products usually do not differ greatly and are made easily accessible to the applicant who wants to price shop, frequently though the newspaper or internet.").

31. See BAR-GILL, supra note 17 , at 161 ("[M] any individuals are not well informed and knowledgeable about their terms of borrowing."). For a survey, see Angelo Capuano \& Ian Ramsey, Financial Literacy Project, What Causes Suboptimal Financial Behavior? An Exploration of Financial Literacy, Social Influences and Behavioral Economics (Univ. of Melbourne L. Sch., Legal Studies Research Paper No. 540, 2011) https://ssrn.com/abstract=1793502 [https://perma.cc/QX62-C5JP].

32. See, e.g., Dan Ariely, The End of Rational Economics, HARV. BuS. REV., Jul.-Aug. 2009, at 78 (criticizing the standard economic theory of rational actors).

33. See BAR-GILL, supra note 17 at 14-15 ("“[P]erfect knowledge of one's preferences cannot simply be assumed.' The central role of use levels as an object of misperception thus highlights the value of a behavioral-economics approach."). 


\section{B. Why Product Regulation is Difficult}

Governmental regulation of credit products goes beyond disclosure. And sometimes these regulations exist in conjunction with mandated disclosure. ${ }^{34}$ For example, the CARD Act includes a number of provisions regulating credit card terms, including banning double cycle billing, allocating payments to the balance bearing the lowest interest rate first, automatically enrolling cardholders in over the limit programs, and forbidding activity fees and convenience fees. ${ }^{35}$ Under the CARD Act, penalty fees must be reasonable and proportional. ${ }^{36}$ It is important to frame these provisions as regulating the terms of products, rather than the terms of contracts, to signify that contract in its classical form is not really at work in the credit market. Rather than bargaining on a bespoke contract, borrowers are buying pre-determined terms and conditions, in the form of the adhesion contract. ${ }^{37}$

There is some doubt that product regulation is effective. From the standpoint of economic theory, if regulation increases the cost of lending and reduces the return, lenders may move their money to more favorable rates of return. This is the theory, but we continue to learn that too many variables cast doubt on its simple logic. It does not account for the fact that consumer lending markets comprise a significant array of market opportunities in the United States; that lenders can structure transactions to mitigate or even eliminate risk through intermediation, ${ }^{38}$ which is subsidized in the home mortgage market; and that sometimes industry prefers regulation when it reduces risk and particularly when industry has influence over the regulatory process.

Like mandated disclosure, product regulation fails to address issues of equality. It reflects a more paternalistic view of credit market regulation than mandated disclosure does. It rests on assumptions that people are boundedly rational and do not understand credit products even if disclosures are made. But it has nothing to do with equality or distributive justice in the credit markets. It has to do with the structure of transactions and not the structure of markets.

III

\section{INTRODUCING EQUALITY INTO ACCESS TO CREDIT INSTITUTIONS}

Much of the attention in access to credit and inequality has been to the invidious problem of racial discrimination in lending, particularly in mortgage

34. E.g., The Home Ownership and Equity Protection Act Rule, 12 C.F.R. $\S 1026.32$ (defining and regulating the terms of high cost mortgages); see generally Michael S. Barr, Modes of Credit Market Regulation, in BUILDING WEALTH: CREATING WEALTH IN LOW-INCOME COMMUNITIES 206 (Nicholas

P. Restsinas \& Eric S. Belsky eds., 2005) (outlining five different types of credit market policies).

35. Credit CARD Act of 2009, Pub. L. No. 111-24, 123 Stat. 1734, 1738, 1739, 1740, 1741, 1752

36. Id. at 1740 .

37. See Jane Margaret Radin, Boilerplate: The Fine Print, VAnishing Rights, And the RULE OF LAW 31 (2014).

38. See PISTOR, supra note 12 at 136 (describing how the intermediary approach enables the legal system of where the entity is incorporated to govern allowing entities to choose jurisdictions with more favorable laws). 
lending. ${ }^{39}$ The Community Reinvestment Act was a substantial policy response mainly to racial inequality. ${ }^{40}$ But an assessment of the Community Reinvestment Act and the obvious moral wrongfulness of racist law and lending practices are beyond the scope of this article. My focus here, rather, is on income and wealth inequality. Some call these distinctions as between status and material inequality, with status referring to the characteristics of persons based on morally arbitrary categories such as race or ethnicity, and material inequality referring to income and wealth. ${ }^{41}$ Of course, some overlap between these categories exists in societies in which racial discrimination is practiced in lending. But inequality, apart from racially discriminatory practices, is a problem worth addressing in a just society, for economic, moral, and political reasons. ${ }^{42}$

The focus of this Part is on equality from a moral point of view as morality applies to institutions. Why material inequality is objectionable is a big subject beyond the scope of this Article and more for a purely philosophical treatment. For our purposes, let us stipulate that law is a cooperative practice in which persons subject to it are in a relationship or association of reciprocity and for these reasons the law and other institutions in the society formed by this cooperative and associative practice, including financial institutions, should not cause or contribute to material inequality. This does not mean that inequality might be objectionable if it arises from desert or natural endowments. As lawyers, we deal in institutions, human-created social practices. The institutions we create are subject to our moral duties to fellow citizens to not promote inequality. Justice, a matter of moral concern in law and politics, comes first as a matter of priority in public policy. We can reach a consensus as to what it is on the basis of settled principles, and law can promote it, or not. The justice we are concerned with here is distributive justice, moral ideas about the distribution of burdens and benefits in a society.

The goal of this Part is methodological ground clearing to begin to develop tools for evaluating access to credit issues. From the standpoint of distributive justice, this Part aims to assist in developing a toolkit to understand what law and economics calls distributional concerns. This toolkit will go beyond simply

39. See RothsteIn, supra note 10; MEHrsa BADARAsan, THE COlOR OF MONEY: BlaCK BANKS AND THE RACIAL WEALTH GAP 115 (2019) (describing the how discrimination impeded lenders ability to provide mortgages to segregated black communities); THOMAS M. SHAPIRO, TOXIC INEQUALITY: HOW AMERICA'S WEALTH GAP DESTROYS MOBILITY, DEEPENS THE RACIAL DIVIDE, AND THREATENS OUR FUTURE (2017).

40. See infra note 69 and accompanying text.

41. See SAmuel Moyn, Not Enough: Human Rights in An Unequal World 213 (2019).

42. On this very general point some philosophers and economists seem to agree though their reasons differ. See T.M. SCANLON, WHY DOES INEQUALITY MATTER (2018) (arguing that the value of equality is non-instrumental, arising from the value of equality itself); JOSEPH E. STIGLITZ, THE PRICE OF INEQUALITY: HOW TODAY'S DIVIDED SOCIETY ENDANGERS OUR FUTURE (2013) (focusing on the importance of fairness and equality in the economy). The political problem associated with inequality, overlapping with moral problems, is domination by affluent groups and distortion of policy choices. See generally MARTIN GILENS, AFFLUENCE AND INFLUENCE: ECONOMIC INEQUALITY AND POLITICAL POWER IN AMERICA (2012) (discussing how public preferences are both shaped by the elite and influence policy outcomes). 
identifying the problem of distribution as a matter of social science empiricism and then seeking to solve the problem through common sense or personal preferences.

Rather, the focus here is on Rawls's theory of justice. ${ }^{43}$ This Article does not in any sense offer an exegetical treatment of Rawls, nor does it advocate a strict adherence to Rawlsian approaches. Since Rawls wrote what is probably the most important set of works in moral and political philosophy in the twentieth century, a post-Rawlsian corpus on egalitarianism has proliferated. Rawls provides an explicit scaffolding by which to understand why and in what circumstances institutions, including law, should be designed to comply with principles of justice. This scaffolding allows us to see clearly why law and other institutions relevant to consumer finance are subject to evaluation using principles of distributive justice.

\section{A. Consumer Finance as a Site for Distributive Justice}

The first question to ask is whether consumer finance is a site of distributive justice. ${ }^{44}$ Not all areas of financial regulation are. ${ }^{45}$ In Rawlsian terms, consumer finance is a site of justice if it is part of the "basic structure of society" and necessary for a person in a society to obtain "social primary goods." ${ }^{46}$ It is unnecessary to hew closely to John Rawls's work, but his conceptions are useful here for articulating a framework to evaluate consumer financial regulation.

The basic structure of society is, according to Rawls, the "primary subject of justice," comprised of institutions that distribute the main benefits and burdens in a society. ${ }^{47}$ The basic structure is "the way in which the major social institutions fit together into one system, and how they assign fundamental rights and duties and shape the division of advantages that arise through social cooperation." 48 It includes the "legally recognized forms of property, and the organization of the economy, and the nature of the family, all belong to the basic structure." 49 According to Samuel Freeman, one of Rawls's former students and a leading expositor of Rawls's philosophy, the basic structure includes the law on "the structure of the economy, including control of means of production and, therewith, laws of property, contract, and other legal measures necessary for

43. See infra note $46-48$ and accompanying text.

44. For an introduction to the site of justice notion, see generally G.A. Cohen, Where the Action Is: On the Site of Distributive Justice, 26 PHIL. \& PUB. AFF. 3 (1997), though I do not follow his argument.

45. See generally Linarelli, supra note 15 (proposing the implementation of a luck egalitarian approach that takes equality into account while holding individuals responsible for their real choices).

46. See generally JOHN RAWLS, A THEORY OF JUSTICE (Harv. Univ. Press rev. ed. 1999); JOHN RAWls: Justice As FAIRnESs: A ReStATEMENT (Erin Kelly ed., Harv. Univ. Press 2d ed. 2001); JOHN RAWLs, POLITICAL LIBERALISM (Colum. Univ. Press Expanded Ed. 2005).

47. RAWLS, A THEORY OF JUSTICE, supra note 46 at 7-11, 15, 54, 84.

48. RAWLS, POLITICAL LIBERALISM, supra note 46 at 258.

49. Id. 
economic production, exchange, and consumption; and certain norms that apply to the family regarding the upbringing of children."

In a Rawlsian framework, distributive justice is about how the basic structure of society distributes social primary goods. Social primary goods are those that are essential for a person to be free and equal in a society and to pursue a good life. Rawls identified "income and wealth" as examples of social primary goods. ${ }^{51}$ Moreover, in a society placing high priority on the accumulation of wealth through private home ownership and the securing of public services through private means, income and wealth are also relevant to the achievement of other social primary goods such as the "social bases of self-respect" and freedom of movement and choice of occupation in the context of economic opportunity. ${ }^{52}$

A broad interdisciplinary consensus has emerged that the institutions of access to credit are part of the basic structure of American society and that they distribute primary social goods. Recent sociological evidence supports these findings. ${ }^{53}$ The American market for credit has historically been substantially subsidized by the federal government. ${ }^{54}$ Legal scholars have gotten the point. Here are just a few select examples. According to Patricia McCoy, "the evidence shows that purchasing a home remains a powerful path - many would say the most powerful path - to building wealth for families of modest means." 55 Adam Levitin and Susan Wachter explain:

It is hard to overstate the importance of housing finance in modern life and in the modern economy. The type of housing finance system we have determines our built environment and the nature and quality of our lives as individuals. It determines where and how we live. It determines who among us can become homeowners, and it determines what kind of houses, what kind of neighborhoods, and what kind of communities we live in. It even affects our ability to participate fully as citizens in our local communities. ${ }^{56}$

Levitin and Wachter go on to explain the institution of the "American Mortgage," the thirty-year fixed rate mortgage created in the New Deal, which only exists in the United States. The American Mortgage would not exist without government involvement. Access to credit provides homeowners with other social goods, besides homes that are essential to achieving distributive justice in a society, such as access to good schools, a clean environment, and low-crime

50. SAMUEl FreEman, Liberalism AND Distributive JuSTICE 231 (2018).

51. See, e.g., RAWLS, POLITICAL LIBERALISM, supra note 46 at 181.

52. RAWLS, JUSTICE AS FAIRNESS, supra note 46 at 58-59.

53. See Dwyer, supra note 5 at 239 ("Three principal approaches have emerged in research on credit and debt that connect to strong traditions of research on inequality: credit and debt in shaping social inclusion and exclusion, the influence of credit and debt on life chances, and credit and debt as elements of opressive social relations."). See generally QUINN, supra note 2 (arguing that increasing access to credit may be more effective in providing citizens with means to acquire basic needs than government funded social aid programs).

54. QUINN, supra note 2.

55. Patricia A. McCoy, Has the Mortgage Pendulum Swung Too Far? Reviving Access to Mortgage Credit, 37 B.C. J. L. Soc. JUST. 213, 214 (2017).

56. AdAm J. LEVITIN \& SusAn M. WACHTER, THE GREAT AMERICAN Housing BubBle: What Went Wrong AND How We CAN PRotect OURSELVES IN THE Future 1 (2020). 
communities. ${ }^{57}$ These social goods could be delinked from access to credit for homeownership through de-financialization. Other societies are so organized. ${ }^{58}$ But we have to deal with the realities of our society if we want our theorizing to be realistic.

Yet still, popular mischaracterizations continue to circulate that housing markets, the housing finance market, and more generally the consumer finance market, somehow operate on their own and only occasionally require government intervention. This is really an ideological narrative, or perhaps it is a misunderstanding of what political scientist Suzanne Mettler calls the submerged state, which underlies the contracts at work in financial markets. ${ }^{59}$ The disclosure versus product regulation dichotomy reflects this ideology of intervention. The intervention language is not helpful for understanding what is really happening in these markets. Law does not intervene in financial markets. Law constitutes financial markets. ${ }^{60}$ Except in some boundary circumstances, markets are just a "bunch of rules." 61

If we adhere to the false narrative of naturally occurring markets in need of occasional intervention, we risk classifying barriers to access to credit as a matter for corrective justice - to correct particular cases of discrimination in lending on an individual basis. Discrimination has been a serious problem in consumer finance but there are also significant structural problems that need to be addressed, including but not limited to structural racism. A focus on isolated transactions is not enough. It is possible to have a mortgage transaction entirely free of discrimination yet still problematic from a structural point of view. A full accounting for justice is not simply about prohibiting denials of credit to individuals, but about how the law shapes the market for credit, with a focus on who gets it and who does not and why, even if individual lenders engage in no discrimination on the basis of race or ethnicity or any other factor.

57. Linarelli, supra note 15 , at 412 .

58. C.f. Leo Kaas, Georgi Kocharov, Edgar Preugschat \& Nawid Siassi, Reasons for the low homeownership rate in Germany, DEUTSCHE BUNDESBANK: RESEARCH BRIEF (Jan. 14, 2020), https:// www.bundesbank.de/en/publications/research/research-brief/2020-30-homeownership-822176 [https:// perma.cc/59UY-8DVR] (explaining how Germany's housing policies incentivize renting).

59. Mettler, supra note 1.

60. Pistor, supra note 12.

61. Robert Reich puts it succinctly:

[T] he "free market" is a bunch of rules about (1) what can be owned and traded (the genome? slaves? nuclear materials? babies? votes?); (2) on what terms (equal access to the internet? the right to organize unions? corporate monopolies? the length of patent protections? ); (3) under what conditions (poisonous drugs? unsafe foods? deceptive Ponzi schemes? uninsured derivatives? dangerous workplaces?) (4) what's private and what's public (police? roads? clean air and clean water? healthcare? good schools? parks and playgrounds?); (5) how to pay for what (taxes, user fees, individual pricing?). And so on.

These rules don't exist in nature; they are human creations. Governments don't "intrude" on free markets; governments organize and maintain them. Markets aren't "free" of rules; the rules define them.

Robert Reich, The Myth of the "Free Market" and How to Make the Economy Work for Us, ROBERT REICH (Sept. 16, 2013), https://robertreich.org/post/61406074983 [https://perma.cc/JWH9-FL6H]. 


\section{B. Principles of Distributive Justice for Consumer Finance}

Having argued that principles of distributive justice have a role in the structuring of consumer finance, the next question is: what are the principles? How do we know when access to credit is good or bad from a distributional point of view? Of course, a number of financial measures are used to evaluate access to credit: credit scores, ability to pay requirements, loan to value ratios for mortgages, loan to income ratios for mortgages, and so on. But these have to do with finance and with individual loan applications and not with equality in the distribution of credit opportunities. When it comes to understanding what it means to say, "this kind of inequality in the credit system is wrong," how do we answer, in terms of methodology and shared consensus on values? We tend to base our views on access to credit on what we feel is right, but this is not good enough for policy making because it fails to offer a route to a consensus. Lawmakers and regulators will not take equality seriously without a methodology for assessing it.

The current prevalent approach to regulatory evaluation is cost benefit analysis. Not all financial regulation is evaluated using explicit application of cost benefit analysis, but it can come into regulation implicitly because some regulators will apply it conceptually in the exercise of expert judgment. ${ }^{62}$ One significant problem for cost benefit analysis is the interpersonal aggregation problem: it aggregates costs and benefits across everyone regardless of their luck, circumstances, position in society, historic injustice, and so on. Interpersonal aggregation is morally problematic because small benefits of a regulation accruing to large numbers of people can be permissibly aggregated to outweigh disproportionate burdens imposed on a lower number of particular persons. Let us assume that there are two benefits to access to credit, one direct and the other indirect. The direct benefit is access to credit itself. The indirect benefit is stability - the idea that lending should not endanger the economy by imposing externalities in the form of systemic risk on everyone. Conceptually, cost benefit analysis without appropriate modification-assuming it can be modified without jeopardizing its validity - is entirely insensitive to inequality. In theory, we could design a very stable credit market by cutting out the poor or even a good chunk of the middle class entirely. Cost benefit analysis could permit access to credit institutions that would prohibit all mortgage lending to anyone that earns an income of less than $\$ 250,000$ if it maximized both direct and indirect benefits. We would likely have a very stable financial system if we cut the poor and most of the middle class out of the credit markets. But given the way American society pegs wealth to access at least to mortgage credit, this approach would be very unjust. The point I make here is simply that the current tools to evaluate financial regulation are insensitive to inequality. I do not argue this set of facts is true but

62. For recent discussions, see generally John C. Coates IV, Cost-Benefit Analysis of Financial Regulation: Case Studies and Implications, 124 YALE L.J. 882 (2015) (discussing cost benefit analysis of financial regulation). 
only that it would be a sound result for cost benefit analysis if the numbers hold. Not all harms are equal if we take distributive justice into account.

There is evidence that the failure to take equality into account in postfinancial crisis regulation of mortgage lending continues to have adverse effects on lower-income households. A study by Laurie Goodman of the Urban Institute, for example, informs that the current rules impose substantial and disproportionate burdens on the less well-off to maintain stability in the financial system. ${ }^{63}$ Goodman has found that mortgage credit has tightened up considerably since the financial crisis. According to Goodman "[m]any loans are not being made that should be." ${ }^{64}$ There has been a decline in home ownership in the United States and a shrinkage of credit. ${ }^{65}$ We need the methodological toolkit to evaluate these findings to get at "distributional concerns" beyond facile descriptions.

Two principles of justice can be deployed to evaluate access to credit institutions. One well-understood moral principle relevant to law and public policy is the difference principle: an institution such as a statute or regulation that creates or perpetuates inequality is morally permissible (or at least not morally wrong) if it makes persons who are less well-off better off. ${ }^{66}$ The difference principle can be understood as a priority for those who are worse off.

One way to develop a method to put into play a priority for the worse off is through what philosopher Frances Kamm calls pairwise comparisons. ${ }^{67}$ In evaluating any law or policy on access to credit, one compares individuals, one at a time, to see how worse or better off they would be with the law or policy. ${ }^{68}$ This may seem a daunting task, but in a time of big data, algorithmic decision tools, and lots of demographic data at hand, pairwise comparison methods should be feasible. The individualist restriction could be somewhat relaxed in the financial context, as like individuals and households often share like circumstances.

With the moral idea of a priority for the worse off implemented in pairwise comparisons, relatively low net worth households have standing to object to mortgage lending policies that place undue burdens on their access to mortgages. What constitutes an undue burden is open to debate, though the argument that access to credit and overall financial stability are tradeoffs is now thoroughly

63. Laurie S. Goodman, Quantifying the Tightness of Mortgage Credit and Assessing Policy Actions, 37 B.C. J.L. \& SOC. JUST. 235 (2017).

64. Id. at 238.

65. See id. at 239-40 ("[L]ow credit borrowers make up a shrinking share of a shrinking bucket."); Jonathan Spader \& Christopher Herbert, Waiting for Homeownership: Assessing the Future of Homeownership, 2015-2035, 37 B.C. J.L. \& SOC. JUST. 267 (2017) ("In the face of the decade-long decline in homeownership, considerable uncertainty continues to exist about both the factors that have contributed to the decline and the homeownership rate's future trajectory.").

66. I have not hewed closely to Rawls's formulation. As I have said, I do not owe strict allegiance to Rawls.

67. Frances M. KAMM, IntricAte Ethics: Rights, Responsibilities, AND PERmissible HARM 57 (2007).

68. Id. 
debunked ${ }^{69}$ We are not dealing with cheap credit or irresponsible, risky lending here. Stability problems can be mitigated through appropriate measures above the level of retail finance, in the intermediation market. The burdens on lower income households caused by restrictions on access to credit include a diminished net worth, a decline in intergenerational flourishing, limited ability to place children in adequate schools, and so on. Higher income households benefit little from access to credit reform. They tend to be less leveraged and with little mortgage debt. Higher net worth households have diversified portfolios and are usually able to bear risk relatively well compared to lower net worth households. Higher income households tend to be, in essence, savers who invest in the mortgage debt of lower income households and therefore often benefit from access to credit. ${ }^{70}$

The above sketch of an approach is not cost benefit analysis. It accords with what in philosophy is known as the separateness of persons requirement or the individualist restriction. ${ }^{71}$ Pairwise comparison requires that each individual be compared to each other individual. That we might make the analysis more tractable by comparing archetypes or representative individuals should hardly matter in the lending context.

Another principle of justice that could be put to work in evaluating access to credit institutions is the fair equality of opportunity principle, which provides that persons with the same natural endowments and willingness to use them should have the same economic opportunities regardless of whether they are rich or poor. Low income cannot determine, on a moral basis, whether a person enjoys the benefits of access to credit, nor, if access to credit is a social primary good, can it restrict homeownership. Equality of opportunity is no doubt at work in many policy approaches aimed at access to credit. The claim for fair equality of opportunity could be more clearly articulated, perhaps to apply more clearly to all forms of inequality, to include material inequality.

Finally, anticipating dubious arguments that this Article advocates socialism for credit institutions, it does nothing of the sort. If anything, the effect of these measures to improve equality in the credit system would be to promote what Rawls called a property owning democracy: a pro-market, pro-private ownership approach requiring widespread and dispersed ownership of property and capital and not concentrated interests, so as to avoid situations of domination that will distort democratic processes. The ideas in this Article align closely to New Deal

69. Access to credit can be designed so that lower income households have access to credit without threatening financial stability. This is not about cheap credit or irresponsible lending. The claim that the last housing bubble was in some measure caused by easy lending incentivized by the Community Reinvestment Act has been thoroughly refuted. See Neil Bhutta \& Daniel Ringo, Assessing the Community Reinvestment Act's Role in the Financial Crisis, BD. OF GOVERNORS OF FED. RSRV. SYS. (May 26, 2015), https://www.federalreserve.gov/econresdata/notes/feds-notes/2015/assessing-the-comm unity-reinvestment-acts-role-in-the-financial-crisis-20150526.html [https://perma.cc/YW8V-ESKA].

70. Atif Mian \& AMIR Sufi, House of Debt: How They (AND You) CAUSED THE Great RECESSION, AND HOW We CAN PREVENT IT FROM HAPPENING AgAin 50, 54-55 (2014).

71. Kamm, supra note 67. 
policy values that have formed the basis for much of the American basic structure of society, but which are being demolished today. If we do not undertake the policy innovations sketched out in this article, we risk aggravating inequality even more. The result will not be a priority for the worse off but rather one for the better off, a wrong direction that inverts the social contract. This inversion converts public duties of justice owed to individuals to private duties of contract owed by individuals, aggravating power and domination dynamics in a society and worsening inequality and its deleterious effects.

\section{IV \\ CONCLUSION}

At best, we are in the nascent stages of developing methods for evaluating access to credit from the standpoint of equality. What is on offer here is mainly an attempt to clarify what should be valued in institutional reform. From the standpoint of institutional change, we have only started the work on status inequality and have done next to nothing about material inequality. Discussions of inequality sometimes produce a more radical approach of suggesting a more significant restructuring of housing and other markets to "de-financialize" the citizen. Here I make a modest plea to work internally and to leave the basic structure of private home ownership and private credit intact. Justice is a first priority for a society and its law. Tackling inequality is one of the most important social goals for our time and it requires a focus on how we distribute credit in American society. 